\title{
XII. New Homoptera Received from the New Mexico Agricultural Experiment Station.-II.
}

\author{
BY CARL F. BAKER.
}

Eutettix pulchella, n. sp.-Size and general appearance of Eutettix (Phlepsius) strobi Fh.

Male: Face two-thirteenths wider than long. Clypeus a half longer than broad, sides gently incurved towards the base, broadened beyond to nearly the width at base, tip truncate. Lorae a fifth longer and three-fourths the width of the clypeus. Genae broadly evenly emarginate below the eyes. Front a fourth longer than wide, two and a third times the length of the clypeus. Vertex rather sharply transversely depressed before the tip, the lip thus formed not strong but very obtusely rounded as viewed from the side; very obtusely rounded in front, length at middle but little greater than that at the eyes, width between the eyes two and an eighth times the length. Pronotum two and one-sixth times wider than long, length nearly twice that of the vertex, curvature seven-twelfths of the length. Plate short, very obtusely angled. Valves somewhat attenuate towards the tips, about four times the length of the plate, clothed on the outer edge with numerous long fine hairs and a few short weak spines.

Color: All beneath pale yellow, with very faint indications of transverse arcs on the front. Vertex back of groove, pronotum and scutel, even shining brown, the brown being thickly covered with small pale dots. The band on vertex may send forward four short more or less distinct points which are equidistant from the eyes and each other. Elytra whitish subhyaline, with brown areas which are thickly covered with fine pale vermiculations. These areas occur as follows: On all of clavus except outer margin of basal two-thirds; from apical third of clavus a clearly defined band passes to costal margin of elytra, towards which it becomes narrower; from the middle of this band a subobsolete band extends to end of elytra, terminating in tips of two outer apical cells. The brown areas on basal half of elytra have sharply defined rather heavy contours. The nervures in basal half of corium are colorless, in apical half brownish. Dorsum of abdomen broadly black. Some of the leg spines darker. Length $4.5 \mathrm{~mm}$.

San Augustine (Ck1l., 2128, 2134, and 2I44). I have also collected this species at Fort Collins, Colorado. The Colorado specimens vary from the typical form in having the brown above very dark, almost black, in being very much darker below, and in other minor points. The specimens of this species, with others of seminuda, a western variety of seminuda, and of Phlepsius strobi, form a most interesting series. Strobi must be placed in Eutettix, with the species of which genus it certainly shows the closest relationships. I hope the female will soon be obtained.

Thamnotettix tenella, n. sp.-Size and general appearence of Thamnotettix caricis, but the vertex is not so produced, and the general color is pale sordid yellowish. Length female $3.25 \mathrm{~mm}$.

Female : Face little more than one-seventh wider than long. Front one-third longer than wide, little more than two times the length of the clypeus, sides slightly incurved at the antennae. Lorae as long and twothirds as wide as the clypeus. Genae broad below the lorae, gently obtusely angled outwardly, from this to the angle of the eye, straight. Clypeus gently narrowed at the base, at the extreme tip somewhat narrowed and truncate. Vertex a third longer at the middle than next the eyes, the length three- 
fifths of the width between the eyes. Pronotum twice wider than long, length once and four-fifths that of the vertex, curvature onehalf of the length, in front with the usual arcuate line. Hind margin of the last ventral segment with a broad deep emargination, the sides of which are strongly sinuate. Pygofers nearly equalling valves, outer apical margins slightly concave, and clothed with long slender hairs.

Color pale sordid yellowish, brightest on the head, darkest on the pronotum. Elytra very slightly infuscated. Abdomen above, except margins of segments, yellowish, margins of some of the basal ventral segments black. Legs with dark dots at bases of tibial spines.

Described from a single female taken at Las Cruces on Sisymbrium (Ckll., 27II). This is the species mentioned on page roo of the Prelim. List. Hemip. Colo. It appears to be a Mss. name of Dr. Uhler's which was never published. It is a quite common insect in various parts of Colorado, and will undoubtedly be found widely distributed in the west. This species could hardly be confused with $T$. caricis, which is larger, of a much brighter yellow, and has a much more produced vertex. It also differs in the form of the last ventral segment. Although a good Thamnotetiix otherwise, yet this species possesses but one anteapical cell in the elytra. Had this character been correlated with the weak form in the definition of Limotettix, I should consider that genus founded on reasonable grounds, and this species a good representative of it.

Athysanus acuminatus, n. sp, - Rather slender, general color pale fulvous; elytra exceeding abdomen. Length male 4.75 $\mathrm{mm}$.

Male: Face little less than one-seventh wider than long. Clypeus once and twothirds longer than wide, gradually broadening to the apex, where it is truncate; sides slightly concave near the base, basal suture curved. Lorae very large, a third longer, and as wide as the clypeus at base, superiorly acute. Cheeks broadly, evenly emarginate below the eyes, sides below the emargination slightly sinuate, moderately broad below the lorae, attaining the tip of the clypeus. Antennae with the six joints following the two basal very unusually robust and distinct (thread-like portion of the flagellum wanting in this specimen). Front one-ninth longer than wide, edges slightly incurved at the antennae, below this straight to the clypeus. Vertex slightly convex, length at eyes fivesevenths of length at middle, the latter threefourths of the width between the eyes. Pronotum two and one-third times wider than long, length a fourth greater than that of the vertex, curvature about three-sevenths of the length, hind margin straight. Elytra exceeding abdomen by about one millimeter, the outer anteapical cell connected with the costal margin by two supernumerary crossveins. Genitalia : Plate subangular posteriorly, somewhat produced at the apex. Valves long triangular, outer edges sinuate and furnished with long fine hair; apices produced in to long, slender acuminate processes which form nearly one-third of the total length. Pygofers a third longer than valves, obtusely but narrowly rounded at tips, furnished on apical half of discs with numerous strong bristles in two or three rows.

Color pale fulvous throughout; slight indications of lighter concentric arcs on the front; indistinct mottlings on anterior borders of pronotum and vertex, the latter with a fine dark median line on posterior one-half. Elytra with one or two small circular or oval white spots on the discs of each cell, these spots surrounded and connected by darker clouding most conspicuous in the apical cells; veins brown, dark towards the apex.

Described from one male taken at Las Cruces in September 1894 (Ckll., 2383). This species differs widely from any other North American species of the genus. It appears to be most nearly related to $A$. 
relativus, but is very distinct from that species in size and other characters.

Agallia bigeloviae, n. sp. - Form and color, nearly, of a small, pale A. sanguinolenta. The female differs only as follows.

More robust. Sculpturing on posterior three-fourths of pronotum not nearly so coarse. Veins in elytra more prominently brown. Two medial brown dashes on pronotum and vertex. Black spots on vertex larger. Elytra barely equalling abdomen. Hind margin of last ventral segment thrice strongly notched, the middle notch very deep and much more obtuse at apex than the lateral, the two lobes thus formed obtusely rounded at tips and much shorter than the hind angles of the segment. Length little more than $2 \mathrm{~mm}$.

Described from a single female taken on Bigelovia at Albuquerque (Ckll., 4616). This species is very nearly related to $A$. sanguinolenta, but easily separated by the above mentioned characters, especially the form of the last ventral segment. A larger series of this insect is much needed for study.

\section{New Species of Prosapis.}

\section{BY T. D. A. COCKERELL.}

The name Prosopis is preoccupied for a genus of plants, on the flowers of which the bees of the genus Prosopis are sometimes found. I have therefore ventured to write the bee-genus Prosapis ( $\pi$ pos-amıs), a name which accords with the assumed fact that it is one of the most primitive among bees.

Prosapis bakeri, n. sp.- $\delta$, length $5 \mathrm{~mm}$., black, with creamy markings, punctures of head and thorax fine and close. Head rather broad; face not much narrowed below, white below level of antennae, the white extending as a pointed projection upwards in median line, and on each side as a club-shaped process, curved over the antennal socket, and remote from the orbital margin. The two sides of the median pointed process meet at an angle of almost $45^{\circ}$. Flagellum very dark brown, paler beneath. Scape swollen, truncate, its anterior side white and posterior side black. Prothorax all dark, except the usual creamy-white spot on tubercles, which presents no dark dot. Tegulae with a yellow spot. Pubescence all pale. Pleura rather hairy, closely and rather coarsely but not very deeply punctured. Dorsal wrinkles of metathorax rather feeble. Wings grayish- hyaline, nervures and stigma piceous. Second submarginal narrowed one-half to marginal. Femora black; tarsi yellowishwhite with the ends darkened; anterior tibiae yellowish-white in front; middle tibiae with the basal fourth, and hind tibiae with the basal two-fifths yellowish-white. Abdomen moderately shining, very minutely punctured, slightly pubescent at sides, but without any conspicuous hair-bands or patches.

Hab. - Colorado; seven miles W. of Livermore, Larimer Co., July r, r 894, 7000 feet (C. F. Baker).

Allied to rudbeckiae, but differs by the white face, the half white scape, and the white frontal process curving over the antennae, etc.

Prosapis wootoni, n. sp.- $\delta$ about $5 \frac{1}{2}$ $\mathrm{mm}$. long, black with pale dull yellow markings, head and thorax closely punctured. Pubescence pale, including that of dorsum of mesothorax. Head rather large and broad, face moderately narrowed below. Antennae entirely piceous, scape only moderately swollen. Face below antennae pale yellow, the yellow forming only a rounded projection in the median line, but at the sides produced upwards 

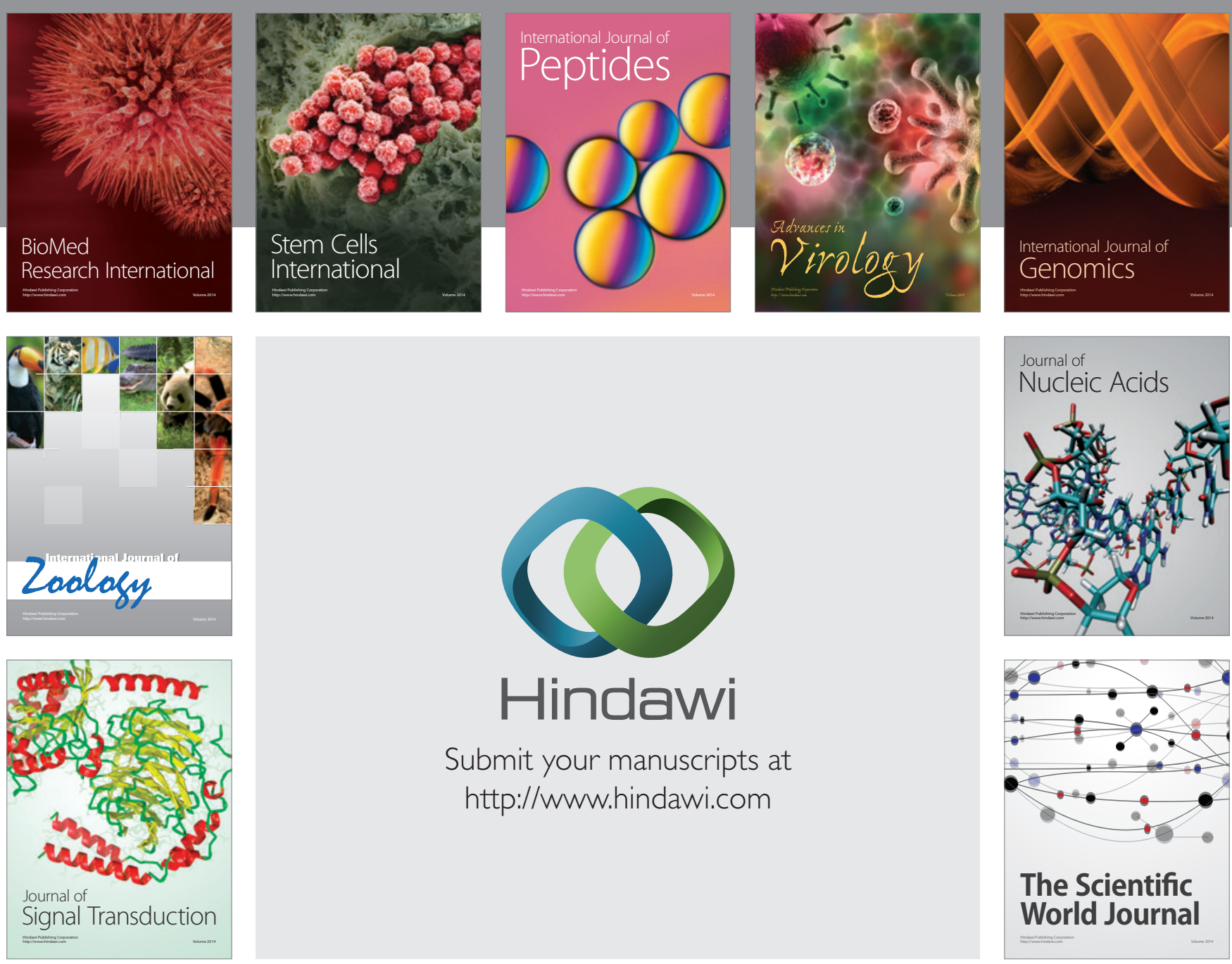

Submit your manuscripts at

http://www.hindawi.com
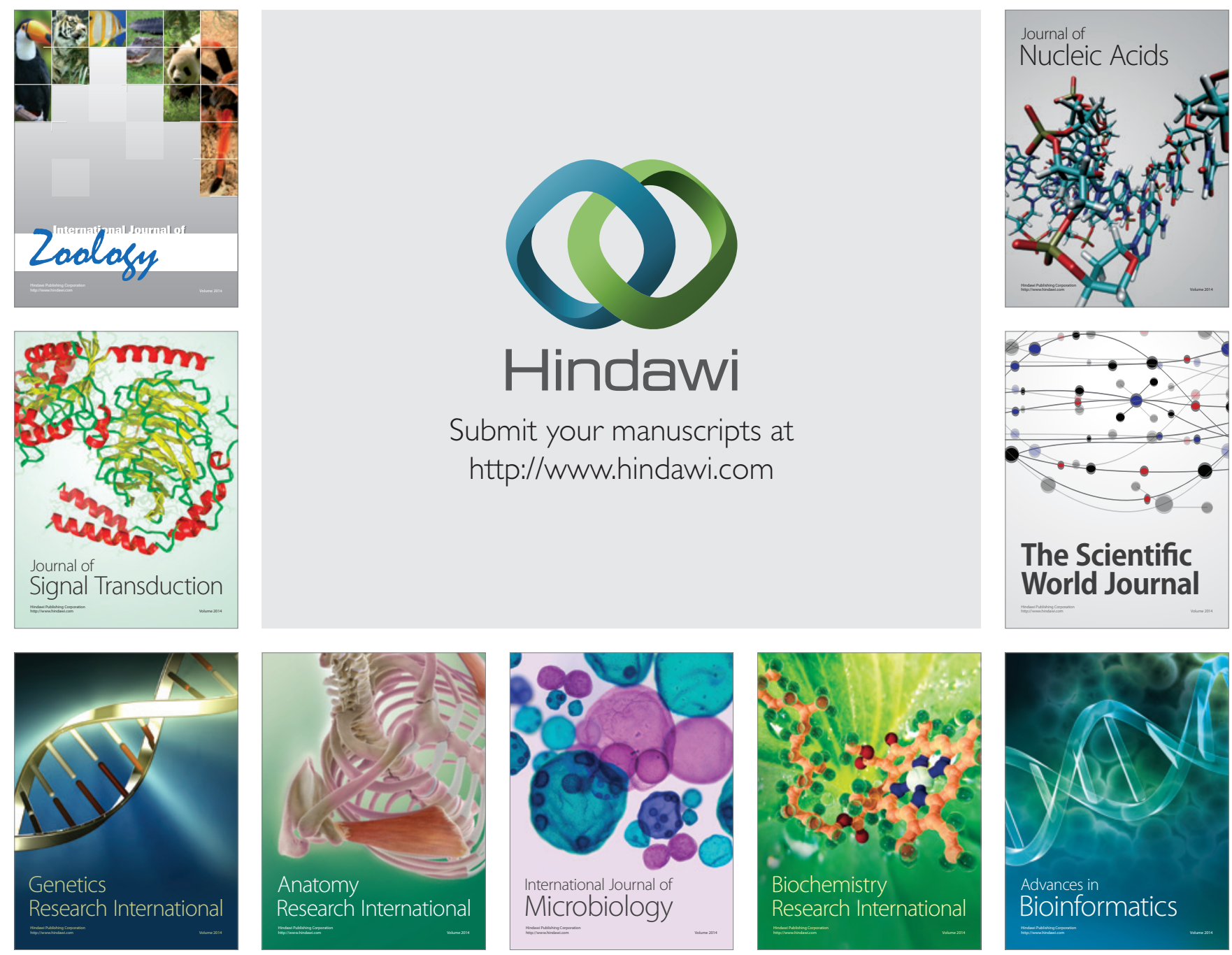

The Scientific World Journal
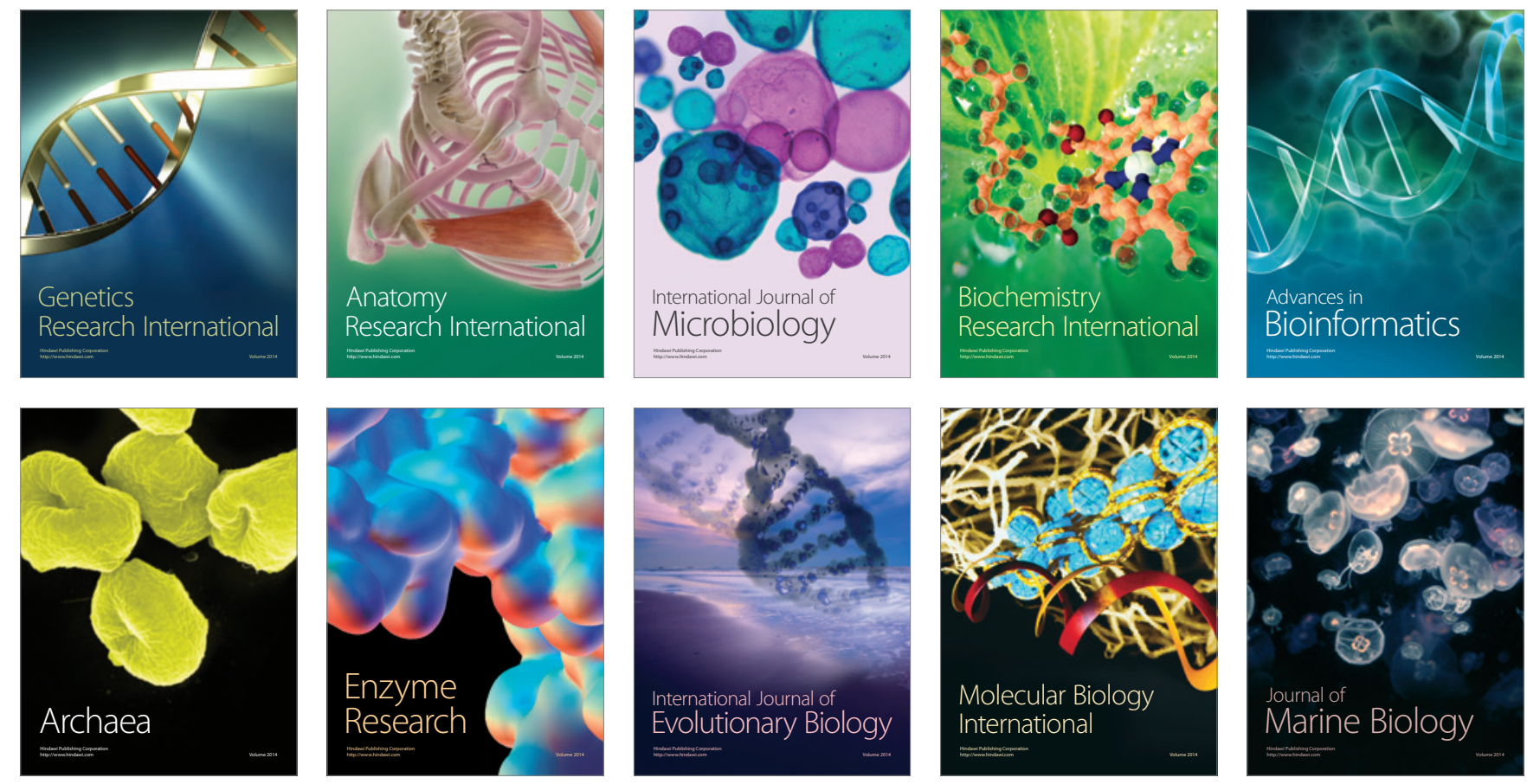